\title{
A novel mechanism underlying pathogenesis of Down syndrome
}

\author{
Xin Wang ${ }^{1,2}$, Yingjun Zhao ${ }^{1,2}$, Xiaofei Zhang ${ }^{1}$, Ying Zhou', Barbara Ranscht', Fred H Gage ${ }^{3}$, William C Mobley ${ }^{4}$, \\ Yun-wu Zhang ${ }^{1,2}$, Stuart A Lipton', Wanjin Hong ${ }^{5}$, Huaxi Xu ${ }^{1,2^{*}}$
}

From Molecular Neurodegeneration: Basic biology and disease pathways

Cannes, France. 10-12 September 2013

\section{Background}

Down syndrome (DS) patients unanimously develop pathologies of Alzheimer's disease (AD) in their 30s or 40s. Since DS is caused by the existence of an extra copy of chromosome 21 in cells, an over-dosage of genes on chromosome 21 may play a role in the pathogenesis of DS and perhaps $\mathrm{AD}$ as well. This idea has been well-supported in the case of the APP gene over-dosage which leads to overproduction of the neurotoxic $\beta$-amyloid $(A \beta)$ peptides, the prime culprit in AD pathogenesis. However, the involvement of other genes on chromosome 21 in AD has barely been studied. Sorting nexin 27 (SNX27), a brainenriched PDZ domain protein, regulates endocytic sorting and trafficking.

\section{Methods and results}

Recently, we showed [1] that $\operatorname{Sn} x 27^{1-}$ mice have severe neuronal pathology in the hippocampus and cortex. Although $\operatorname{Sn} \times 27^{+/-}$mice have grossly normal neuroanatomy, we found defects in synaptic function, learning and memory and a reduction in the amounts of ionotropic glutamate receptors (NMDA and AMPA receptors) in these mice. SNX27 interacts with these receptors through its PDZ domain, regulating their recycling to the plasma membrane. We demonstrated a concomitant reduced expression of SNX27 and CCAAT/enhancer binding protein $\beta(C / E B P \beta)$ in Down's syndrome brains and identify $C / E B P \beta$ as a transcription factor for $S N X 27$. Down's syndrome causes overexpression of miR-155, a chromosome 21-encoded microRNA that negatively regulates C/EBP $\beta$, thereby reducing SNX27 expression and resulting in synaptic dysfunction. Upregulating SNX27 in the hippocampus of Down's syndrome mice rescues synaptic and cognitive deficits. In addition to its role in DS, we also found that over-expression of SNX27 dissociates PS1 $/ \gamma$-secretase complex and reduces the level/ activity of $\gamma$-secretase and the production of $\mathrm{A} \beta$, whereas and depletion of SNX27 results in increased $\gamma$-secretase activity and $\mathrm{A} \beta$ production.

\section{Conclusion}

Our identification of the role of SNX27 in synaptic function and in regulating $\gamma$-secretase activity and $A \beta$ generation establishes a new molecular mechanism for pathogenesis of both DS and AD.

\section{Acknowledgements}

We thank P. Slesinger (Mount Sinai School of Medicine) for providing the rabbit SNX27-specific antibody and helpful discussion, A. Roberts and the Scripps behavioral core for mouse behavioral analysis, T. Golde and C. Ceballos (University of Florida) for generating AAV, E. Masliah (University of California, San Diego) for providing human brain specimens, P. Greengard (The Rockfeller University) for providing GluR1 and GluR2 constructs, K. Wright (University of California, San Diego) for helping in the transfer of Ts65Dn mice, S. Huang (Sanford-Burnham Medical Research Institute) for helping with statistical analysis, K. Saylor and P. Johnson (NIH) for C/EBP $\beta$ knockout mouse breeding and tissue collection, and A. Brzozowska-Prechtl and L. Lacarra for technical help. This work was supported in part by US National Institutes of Health grants (R01 AG038710, R01 AG021173, R01 NS046673, R01 AG030197 and R01 AG044420 to H.X.; and P01 HD29587, P01 ES016738, P30 NS076411 to S.A.L.) and grants from the Alzheimer's Association (to H.X. and Y.-w.Z.), the American Health Assistance Foundation (to H.X.).

\section{Authors' details}

${ }^{1}$ Sanford-Burnham Medical Research Institute, La Jolla, California, USA. ${ }^{2}$ Fujian Provincial Key Laboratory of Neurodegenerative Disease and Aging Research, Medical College, Xiamen University, Xiamen, China. ${ }^{3}$ Laboratory of Genetics, The Salk Institute for Biological Studies, La Jolla, California, USA. ${ }^{4}$ Department of Neurosciences, University of California San Diego, La Jolla, California, USA. ${ }^{5}$ Institute of Molecular and Cell Biology, Singapore. 


\section{Reference}

1. Wang $X$, et al: Loss of sorting nexin 27 contributes to excitatory synaptic dysfunction by modulating glutamate receptor recycling in Down's syndrome. Nature Medicine 2013, 19:473-480.

doi:10.1186/1750-1326-8-S1-023

Cite this article as: Wang et al:: A novel mechanism underlying pathogenesis of Down syndrome. Molecular Neurodegeneration 2013 8(Suppl 1):O23.

Submit your next manuscript to BioMed Central and take full advantage of:

- Convenient online submission

- Thorough peer review

- No space constraints or color figure charges

- Immediate publication on acceptance

- Inclusion in PubMed, CAS, Scopus and Google Scholar

- Research which is freely available for redistribution

Submit your manuscript at www.biomedcentral.com/submit 